The "Datafication" of teaching: Can teachers speak back to the numbers?

\title{
Howard Stevenson
}

University of Nottingham

Correspondence should be sent to: School of Education, Jubilee Campus,

University of Nottingham

Nottingham

NG8 1BB UK

howard.stevenson@nottingham.ac.uk 


\begin{abstract}
:
Teachers face considerable and increasing pressure in their working lives. Labor intensification compels teachers to work faster, harder and longer. However, teachers also experience increasing external control over what they teach and how they teach. These processes are increasingly made possible by the "datafication" of teaching, whereby the educational process is increasingly transformed into numbers that allow measurement, comparison and the functioning of high stakes accountability systems linked to rewards and sanctions. Whilst there is no question that being able to use student assessment data to support learning has an important place in teachers' repertoire of skills, "datafication" refers to the use of data in a way that has become increasingly detached from supporting learning and is much more concerned with the management of teacher performance as an end in itself. This article presents two currents of critical thought in relation to teachers' work, labor process theory and post-structural analyses grounded in the concept of performativity, and discusses them as a way of "making sense" of teachers" work and the "datafication" of teaching, with a particular focus on questions of control and resistance.
\end{abstract}

It seeks to understand why, despite the pressures on teachers, teacher resistance has seldom developed in ways, at times, or on a scale, that both experience and theoretical insight might have predicted. There are clearly significant differences between the two perspectives presented in this article, not least in the ways they conceptualize and explain "resistance." However common ground is identifiable and the two theoretical approaches can be bridged in a form that can be productive for those seeking to "speak back to the numbers." In looking to broker this theoretical divide, I argue that frame theory, rooted within the sociology of social 
movements, can offer a fruitful way of theory bridging, whilst also providing the basis for a wider politics of transformation. The article offers several examples of grassroots initiatives formed to oppose standardized testing in England and which provide practical examples of this "ideas work" in action. 


\section{INTRODUCTION}

In almost every part of the world, teachers experience similar pressures. Expectations are rising, often fueled by the competitive drive of global league tables (Sellar \& Lingard, 2014). Quick fixes are sought to address the problems of systems often characterized as broken and failing (Levin, 1998). Change is constant and seems to take place on a scale, and at a pace, that is unprecedented. It can appear as though everywhere there is a restlessness and everything is urgent. At the same time, there is a downward pressure on public investment in education. Even before the economic crash of 2008, a global orthodoxy of tight public money was well established, and since the crash austerity-driven pressures to contain public spending have amplified (Sen, 2015). Within public education systems, teachers face a squeeze between efforts to drive system "output" up (increasingly gauged in terms of standardized test scores), and a simultaneous pressure to keep costs down.

Teachers experience these pressures in the form of a relentless drive to "raise standards" whilst the test scores generated to measure "output" are in turn used to compare teacher against teacher, school against school and, increasingly, nation against nation (Apple, 2005; Steiner-Khamsi, 2003). Central to these developments is the transformation of complex educational processes into data points which can be used to sort, order, benchmark, compare and rank. Numbers, and "data," become increasingly significant in framing the working lives and experience of teachers (Ball, 2015), often made possible by the increased use of technology.

The measurement of everything is central to the modern educational experience, whereby success is framed in terms of targets achieved and performance is evaluated through ever more complex metrics (Grek, 2009; Grek, 2015; Ozga, 2009). Teachers and schools that 
fail to meet specified targets are increasingly met with punitive responses. It seems as though it is not possible to speak back to the numbers because the numbers speak for themselves. Numbers assume a form of objective reality that is apparently beyond question (Taubman, 2009). Consequently teachers not only experience a relentless intensification of their labor, but this is compounded by a growing sense of alienation as teachers are compelled to focus on outputs over individuals (Allen, 2014). This experience is captured in the reflections of an English teacher whom I interviewed in 2007:

There are demands put on you about teaching your subject. But my personal feeling is to be a good teacher you have to have a relationship with these children and, and they want it. They need it. I mean they don't have to like you but you have to have the respect, you have to have the time to build the relationships with them ... . but maybe we don't have the time to build those relationships because statistics say ... data says ... target says ... the child becomes a number that you have to teach.

It's all about the statistics, their data . . their targets, as opposed to building the relationship with the child

(interview data from Carter \& Stevenson, 2008)

This focus on the changing nature of teachers' work must inevitably focus on questions of control, and what, more specifically, Goodrich (1920) called the "frontier of control" as the point of contestation between managerial authority and worker autonomy. In this article I am interested in understanding how the forms of control that that have reengineered these changes in teachers' work are underpinned by what Roberts-Holmes (2015) has called the "datafication" of teaching, and what Stephen Ball (2015) has referred to as the 
“tyranny of numbers." In turn, I am concerned with how these experiences of control open up possibilities of "resistance" 1 and "movement building spaces" (Anyon, 2014, p. 178). In summary, how might we connect the "datafication" of teaching with teachers' preparedness to "speak back to the numbers?"

My focus on developments in teachers' work, and in particular on questions of control, point to theoretical frameworks which begin with a critical questioning of the often unquestioned assumptions about "continuous improvement" underpinning much school effectiveness and improvement literature. Such questions have long been recognised as central to the study of teachers' work (Gewirtz, 1997; Ingersoll, 2009; Moe, 2002). However, in this article, I focus on two particular currents in the study of teachers' labor, which both offer sharp critiques of contemporary developments in teachers' work and seek to explicitly connect the experiences of teachers with the responses of teachers, specifically the possibilities of resistance. The two currents might be located in the structuralist and the poststructuralist traditions respectively. First, labor process theory is grounded in Marxist analyses of work. It emerged in its modern form following publication of Harry Braverman's highly influential "Labor and monopoly capital" (Braverman, 1974) and has been applied specifically to teachers' work. Second, and more recent, is a post-structuralist current that draws on Foucault's (1977) notions of power and has coalesced around Lyotard's (1984) concept of performativity.

\footnotetext{
${ }^{1}$ In placing this in parenthesis I am framing the notion of resistance in its broadest sense. Organized acts of collective resistance are extremely important, but for the purpose of this article the definition of resistance is much more catholic. The intention in part is to problematize, rather than romanticize, what resistance can mean, and the forms it might take.
} 
The two approaches are grounded in quite different traditions and these differences and their implications and explored. However, I also identify where there are commonalities in approach, where one might be used to inform the other, and where elements of cross-over may allow for a type of productive fusion. I want to argue that frame theory, a particular tradition within the sociology of social movements, offers a basis for this type of theorybridging. Frame theory focuses on how those in "controlled settings" (Noakes \& Johnston, 2005, p.3) reject the authoritative version of reality (Gamson, Fireman \& Rytina, 1982) and begin to "reframe" their context in a way that exposes injustice and thereby opens up the possibility of a challenge to the orthodoxy. Frame theory has been described as "bringing ideas back in" (Oliver \& Johnston, 2000, p. 37) to the study of social movements, and I argue that recognizing the importance of this "ideas work" is essential, if collective resistance is to develop from individual grievances and a sense of injustice. Included in the analysis are several examples of grassroots initiatives that have been formed to oppose standardized testing in England and which serve to illustrate this reframing in action.

My principal aim here is to "think through" an apparent impasse in critical approaches to understanding teachers' work and resistance caused by a theoretical polarization within critical traditions. This article also seeks to "think beyond" this unconstructive intellectual standoff which I believe is unhelpful to those actively engaged in mobilizing collective responses to datafication in teaching. In using frame theory to "theory bridge" I argue it becomes possible to suture together competing perspectives, and thereby develop the theoretical pluralism necessary for understanding contemporary developments in teachers' work. 


\section{PERSONAL PERSPECTIVE AND REFLECTION}

In writing this article I am confronting issues in my own history that I have wrestled with, but which now seem more troubling than ever. As an educator I have always seen myself as an "activist" of some description (principally through my membership of, and participation in, education labor unions in both the school and higher education sectors). During this time I have sought to develop collective responses to increases in managerial control and efforts by both the state and employers to roll back the frontier of control at the expense of educators. Although I have participated in many successful initiatives, it has often seemed as though the tide of reform has only slowed but not stopped, and certainly not reversed. Collective resistance has often failed to materialize when, or in forms, that I had assumed and hoped it would. These frustrations in my activist life have also been mirrored in my academic life, where the collective mobilizations of teachers that I and other scholars have predicted have seldom materialized. On the contrary, Hall and McGinity's (2015) study of recent education reform in England claims that there is "a high level of compliance amongst teachers working in schools in England with regards to the reconceptualization of their work and their identities" (p. 3).

It is as though a whole raft of certainties that have guided my life, most obviously "the worse it gets (in terms of material conditions), the better it gets (in terms of collective resistance)") no longer apply, if indeed they ever did. To borrow from the reflections of Michael Burawoy, writing thirty years after he commenced work on "Manufacturing consent" (1979), I wonder if "I was blind to the future that was already opening before me" and in being "riveted to the past ... I had my back to the future" (Burawoy, 2004, p. 3). This 
is therefore a personal project to make sense of matters that have guided my life, but on the basis of thirty years of experience as an activist, I now feel that I understand less than ever. In my own personal reflections in this article, I hope that I might also provide some insight to the public school teacher in my master's class who commented on the tension she experiences in her professional life between what she believes in and what she does every day - "This course has made me realize I don't really like who I am at work."

In some very modest way I hope that this article might help her make sense of her world and help her understand how she might change it. It does not claim to provide answers, but is offered in the belief that engaging in a dialogue about troubling questions is the starting point for the possibility of political transformation (Apple, 2013; Freire, 1970).

I am writing from the perspective of someone who has always studied and worked in the English education system. Many of the developments that are the concern of this article are global in their form (Robertson, 2000; Spring, 2014), but I leave it to others to judge to what extent the analysis I present, inevitably a product of my own history, is reflective of developments and experiences in other parts of the world. England can be considered as the crucible of neoliberal restructuring in both K-12 schools (Jones, 2016) and universities (Slaughter \& Leslie, 1997) but these are policies that have travelled far and wide (Ball, 1998, Rizvi and Lingard, 2010). Readers must make their own judgement about how, and in what ways, the globalized forces of homogeneity are tempered by the specifics of local context.

Finally, in trying to "make sense" of these issues, this article is theoretical in its orientation and ambition. It is not an empirical study although it draws on previous empirical studies I have participated in. I also draw on several practical examples of activism and 
campaigning to illustrate the possibilities of resistance which I believe are opening up as teachers, and others, "speak back to the numbers." However my principal intention is to "think aloud" about how competing theoretical perspectives might be bridged in ways that do not just help us to understand resistance, but to develop it. It is unapolgetically uncertain, but it is no less ambitious for that.

\section{TEACHERS' WORK AND LABOR PROCESS THEORY - CONTROL FROM ABOVE}

Raewyn Connell's classic study "Teachers' work" (1985) highlighted the importance of recognizing "teachers are workers, teaching is work and the school is a workplace" (p. 69). Teaching is viewed as a labor process in which those who are able are required to sell their labor power in a market exchange. Employers then have the task of transforming labor power (the ability to work) into work itself and this task is the function of management. Labor process analysis is rooted in the Marxist tradition and focuses on questions of control and the imperative to realize value in the production process (Marx, 1990). Underpinning this analysis is the premise that work takes place within a specific set of capitalist social relations and that those relations are necessarily antagonistic and conflictual. The goal of the employer is to maximize surplus value as the basis for generating profit, and from this imperative emerges the potential for a struggle over the distribution of value created. Collective resistance, at some point and in some form, becomes the inevitable outcome as workers seek to reclaim the value their labor has created.

Presented in this form, such a debate can seem obtuse and even irrelevant to the work 
of many teachers. The vast majority of teachers work in public systems and the notion of surplus or profit can seem alien (although the growth of for-profit sectors, sometimes within public systems (Verger, Fontdevila \& Zancajo, 2016), may make this process of exploitation increasingly transparent). Such teachers are not involved in the production of a good or service for sale, and indeed it is not immediately obvious what it is that teachers "produce" (Carter, 1997) or what "value" means in a teaching context (Harvie, 2006). Given these complexities it is tempting to argue that labor process analysis has little to contribute to an understanding of developments in teaching and teachers' work (Bach, Kessler \& Heron, 2006).

In this article I want to argue that labor process analysis continues to be relevant to understanding teaching but that early applications of labor process theory to teachers' work were limited, and these limitations have only in part been addressed by more recent contributions.

Interest in labor process theory emerged following publication of Harry Braverman's "Labor and Monopoly Capital" (1974) in which he argued that work was becoming increasingly routinized so that "low skill" elements of any task could be reallocated to less qualified, and cheaper labor (what Braverman described as "the separation of conception from execution" p. 114). The increased division of labor, and concomitant de-skilling, would not only drive down costs but also increase managerial control in ways first anticipated by F.W. Taylor's advocacy of scientific management (Taylor, 1911) or what Seifert and Li (2014) have more recently referred to as “neo-Taylorism.” Braverman's analysis was focused largely on the labor process of manual workers, but attention was also devoted to analyzing 
de-skilling trends in white collar clerical work.

This de-skilling thesis, and its associated claim of "proletarianization," was quickly applied to teachers (Carlson, 1987, in the USA; Ozga \& Lawn, 1981, in the UK; Smyth, 2001, in Australia). Carlson (1987) for example highlighted the growth of standardized and scripted curricula and the use of unqualified labor, both of which remain important issues thirty years later (see Horn, 2014). For Carlson, further evidence of proletarianization was provided by the transformation of American teachers' collective organizations from conservative professional associations into more militant labor unions (Golin, 2002; Murphy, 1990). Parallel developments were evidence elsewhere. For example, in England the first ever national teachers' strike had taken place in 1969 and there were increased signs of teacher militancy throughout the 1970s and 1980s (Seifert, 1987). Indeed in the mid-1980s in England, teachers entered into a protracted industrial dispute (lasting from 1984 through to 1986) which was ostensibly about pay, but as The Times newspaper recognized, was really about the future direction of education reform in England, and therefore by implication, a struggle over teachers' work and the "frontier of control."

At the heart of the teachers' dispute is not money but management... This dispute is about resistance to change in working practices. (The Times, $19^{\text {th }}$ March 1985, quoted in Ball, 1988, p. 296-297)

This radicalization of teacher unions, and the concomitant growth in militancy, was initially seen as the vindication of the proletarianization thesis which assumed that the "workerization" of teachers (de-skilling and labor intensification) would lead inevitably to collective resistance and industrial action. In England, however, the teachers' dispute ended 
in defeat (Rieser, 2016), whilst in the USA teacher union militancy appeared to have been absorbed into bureaucratic collective bargaining processes (Hannaway \& Rotherham, 2006). It was as though the demoralization that followed these setbacks for militant teacher unionism also presaged dissatisfaction with the explanatory power of labor process analysis to link attacks on teachers' labor process with collective responses by teachers. Any conception of "proletarianization" was clearly more complex than some had suggested and the apparent inevitability of resistance was certainly not assured. With this lost sense of inevitably interest in labor process analysis ebbed.

However, since these developments, there has been renewed interest in labor process theory and its relevance to teachers with an explicit intention to address deficiencies exposed in earlier iterations of the approach (Carter \& Stevenson, 2012; Stevenson, 2007; Reid, 2003). This interest almost certainly emerged from a recognition that labor process analysis continues to offer a powerful analysis of, and explanation for, many developments in teachers' work, even if it might not act as a reliable predictor of future action. Reid (2003), for example, argued that labor process analysis in relation to teaching had been overdependent on the concept of de-skilling and the process of proletarianization, both of which represented an obstacle to more fully understanding changing developments in teachers' work. Reid makes the case for labor process analysis to move beyond a preoccupation with the detail of teachers' work (what teachers do) and to focus on understanding how their work is organized. This re-affirmed a need to see the control function of management as central to labor process analysis and to shift focus from the effects of control to the purpose and forms of control. For Reid the need for increased control derived not only from the need to intensify the labor of teachers (get "more for less" according to Sinclair, Ironside \& Seifert, 1996), but 
also to assert more control over the qualitative nature of teaching, or what teachers teach, recognizing the vital and distinctive ideological function performed by teachers within the capitalist state (Apple, 2004). Appreciating the ideological role of teachers becomes essential to understanding why questions of control have loomed so large for teachers, and arguably much more so than for other professions.

Central to Reid's argument is that labor process theorists need a more nuanced analysis of how teachers' work is controlled, and in particular how compliance is secured through teachers' consent; themes also developed by Bob Carter, Rowena Passy and myself (Carter, Stevenson \& Passy, 2010) in our study of a teacher labor force reform in England and Wales between 2003 and 2008.

Our work was based on an empirical study (Carter \& Stevenson, 2008) of a package of reforms referred to as "workforce remodeling" (DfE, 2003). In essence the reforms were intended to address teachers' concerns about rising workloads, whilst also maintaining a focus on the government's "standards agenda" (the government's own phrase to describe its focus on raising standardized test scores). Distilled to its most basic form, the reforms sought to reduce teacher workload whilst simultaneously raising tests scores. This was to be secured by ensuring teachers focused on the "core task of improving teaching and learning" (RIG, 2005, para 2.7) whilst teaching assistants (TAs) undertook "non-core" tasks. At one level this was uncontentious, with little dispute about the use of TAs to undertake a range of administrative and bureaucratic roles that teachers believed were a poor use of their time (e.g., undertaking bulk photocopying or data inputting). However, in other areas of teachers' work, the changes were far more contentious. One teachers' union refused to support the 
policy as it provided for "cover supervisors" (teaching assistants) taking responsibility for the classes of absent teachers (classic labor substitution of the type identified by Carlson, 1987). Another tendency that emerged was a sharpening division between the narrow academic and wider pastoral roles of teachers. There was evidence that responsibility for the latter was being passed to those in teaching assistant roles (most of whom were women), thereby reinforcing a particular, and gendered, perspective about the "core task of teaching and learning" in which "caring" was reallocated to cheaper, largely female, labor (HammersleyFletcher, 2008).

Workforce Remodeling, with its emphasis on the efficient deployment of labor, displayed many of the key features of Taylorist scientific management. Certainly the increased use of less qualified and cheaper labor pointed to processes of labor substitution and deskilling. However, this was also accompanied by much greater use of performance data in order to measure output and productivity. Performance pay systems were expanded with growing evidence that student test data was a key driver underpinning judgements. Classic Taylorism had always relied on the ability to quantify the value of each worker to insure that the rewards and sanctions that underpin scientific management can be correctly applied (Taylor, 1911). Standardised testing, combined with improved technology for "data harvesting" now provided an architecture to assert much more direct control over teachers' work. In such a system the increased quantification of individual teacher performance provided the "science" used to legitimate the new scientific management.

However, as our study sought to demonstrate, attempts to present a clear and unambiguous picture of deskilling, and hence proletarianization, were problematic. Although 
there was evidence of a separation of conception from execution (with evidence of a division of labor between those who design and those who deliver), there was also considerable diversity of practice across individual schools and a counter-narrative of "new professionalism" (RIG, 2005) framed around professional standards and increased accountability (Carter, Stevenson \& Passy, 2010). The fragmentation of work and its redesign were apparent, but so, too, was an increased flexibility with the erosion of sharp divisions of labor allowing a more fluid approach to job roles. Taylorist approaches to work offered only part of the explanation of workforce reform. Echoing Reid (2003), it was clear that a much more fruitful approach to labor process analysis was a focus on the organization of work, rather than a narrow concern with labor substitution and de-skilling.

Within our study the focus on the mechanisms of control and compliance was evident in the emergence of an "extended managerialism" (Carter, Stevenson \& Passy, 2010, p. 137) whereby control from above was driven downwards within the organizational structure through the growth of a cadre of "middle leaders." These middle leaders became increasingly responsible for the performance of those they "line managed," and in so doing, often became detached from their classroom teacher colleagues.

This transformation of the role of the middle leader becomes central to understanding the new labor process of teaching. Rather than a simple divide between "conception and execution," what emerged during the period of workforce remodeling was an increasingly blurred distinction between the two. Middle leaders increasingly took on a role enforcing the target-driven objectives imposed by the state on school management and transmitted within schools through management. Not only did this extension occur through the involvement of 
middle leaders in a range of managerial practices (lesson observation, increased performance monitoring, pay determination) but it also extended the ideology of management deeper into the workforce. One principal in our study described it as the creation of a group of "miniprincipals" in her school whereby a language of "distributed leadership" (Carter, Stevenson \& Passy, 2010, p. 92) masked a process of managerialization in which so-called middle leaders had responsibility (and accountability) but little meaningful autonomy.

Our research was, above all, a study in labor relations, and hence, our interest in the study on forms of resistance focused on teachers' collective organization, specifically their unions. In the book that details the project (Carter, Stevenson \& Passy, 2010), we set out how collective teacher resistance to the increased managerial control of teachers' labor offered the prospect of a form of union renewal (Gall, 2008; Fairbrother, 1996, 2000; Kumar and Schenk, 2006) involving a commitment to challenge neoliberal restructuring, as well as "transformed union forms and relations based more on workplace organization and membership participation" (Carter, Stevenson \& Passy, 2010, p.156). Put simply, we argued that increased tensions in the workplace, arising from workforce reform and attacks on teachers' labor process, provided opportunities for union organization to mobilize teachers and to push back the frontier of control in favor of educators and at the expense of the new managerialism.

In our conclusion we speculated that the Taylorization of work embedded within the workforce reforms (labor substitution, deskilling, increased performance monitoring and surveillance), combined with post-economic crisis austerity (at that point already emerging), would presage increased resistance and would lead inexorably and inevitably, to an organized challenge from below. In reality, in the decade since that research was completed, reforms 
have continued apace, whilst teachers' collective resistance has been insufficient to challenge the trajectory of policy.

With hindsight, it seems we were culpable of the same residual determinism that had been a feature of the first wave of labor process theorists, and which pointed to the inevitability of collective challenge. Whilst it is undoubtedly the case that work related grievances are often a precondition for action such a point fails to adequately acknowledge Noakes and Johnston's (2005) assertion that "there is no simple relationship between injustice and mobilization. Injustice is much more common and much more persistent than collective efforts to oppose it" (p. 1). Merryn Hutchings made this argument in her review of our book (Hutchings, 2010). Based on her substantial research into different aspects of the workforce remodeling programme and its implementation (Hutchings et al., 2009), her observation was that there was "very little evidence of resistance to the various reforms" (Hutchings, 2010, p. 112). This analysis is echoed by Hall and McGinity when, in their more recent study of teachers' responses to radical system reform they observed "very little evidence of overt resistance and precious few hints of covert resistance" (Hall \& McGinity, 2015, p. 12).

Hutchings offers a number of explanations for this lack of resistance, including the incremental nature of the reforms and the popularity of some elements of the reforms (such as non-contact time for primary school teachers, or limits on covering for absent colleagues). However, her more fundamental point was that "there also seemed to be something about the way that teachers define themselves and their role that made resistance unlikely" (Hutchings, 2010, p. 112). In elaborating her argument, and drawing on her own study, Hutchings made the following point: 
Some of the teachers interviewed about their planning practices reported a strong culture of monitoring and accountability, but rather than resisting it, some, particularly in primary schools, tended to respond with feelings of inadequacy. While this was described as pressure that they put on themselves, it could only have arisen in a context where plans are sometimes scrutinised. One experienced primary teacher told us that she wrote detailed plans "because I'm frightened not to." (Hutchings, 2010, p. 113)

This analysis by Hutchings highlights what remains a significant problem in labor process theory. As a way of theorizing developments in teachers' work, labor process analysis continues to provide coherent and cogent critique. The increasing intensification of teachers' labor, associated de-skilling and the growing use of performance related pay systems as a means of control are all consummate management strategies from a labor process perspective. Much of this approach depends on the quantification of teacher performance that makes measurement, and therefore comparison, possible. Indeed rooting an analysis of teachers' work as first and foremost a process of exploitation may become more obvious as for-profit provision expands (Verger, Fontdevila \& Zancajo, 2016) and the processes of exploitation become more visible. However, even with a focus on the "forms and purpose of control" (Reid, 2003), rather than the less helpful focus on "proletarianization," labor process analysis fails to adequately reflect the complex ways in which consent is manufactured and compliance is secured. Fear, underpinned by draconian management systems, clearly play an important part in securing control (Stevenson \& Wood, 2013) and help to explain why teachers may be reluctant to challenge what many of them 
believe is a punishing system. However, such an explanation fails to recognize or explain "how teachers had been overwhelmingly won over to accepting and/or embracing neo-liberal reforms" (Hall \& McGinity, 2015, p. 12). Whilst many, including myself, would contest Hall and McGinity's assertion of co-option on this scale (see Berry, 2016), and it is always important to acknowledge the daily acts of resistance of organized teachers (see www.teachersolidarity.com), few would challenge the assertion that the English school system has been transformed along radical neoliberal lines and that much of this has been accomplished in the face of limited opposition. Given these conclusions it is important to look elsewhere to develop an analysis that is able to explain the phenomena being discussed.

\section{TEACHERS' WORK IN AN AGE OF PERFORMATIVITY - CONTROL FROM WITHIN}

Those who are critical of the neoliberal turn in education policy and its impact on teachers, teaching and the experience of students, but who are uncomfortable with the determinism often associated with labor process analysis, have looked elsewhere for the thinking tools that can help understand the developments in teachers' work. Ball (2013) explicitly rejects the need to commit to a particular theoretical or disciplinary standpoint, or to be aligned with "some orthodoxy or community of like-minded scholars committed to a single theoretical position" (p. 1-2) and argues that scholars need to be free to find spaces beyond, or indeed in between, traditional theoretical approaches from which it becomes possible to offer analysis and critique. He recognizes the scale and significance of the shift in education policy identified in the analysis above, and much of the analysis is shared. However, drawing on the work of Foucault in particular, he argues the distinctive nature of 
these reforms is embedded within particular policy technologies of the market, managerialism and performativity. In this context performativity is described as:

... a technology, culture and a mode of regulation that employs judgements, comparisons and displays as means of incentive, control, attrition and change - based on rewards and sanctions (both material and symbolic). The performances (of individual subjects or organizations) serve as measures of productivity or output, or displays of 'quality', or 'moments' of promotion or inspection. As such they stand for, encapsulate or represent the worth, quality or value of an individual or organization within a field of judgement. The issue of who controls the field of judgement is crucial. One key aspect of the current educational reform movement may be seen as struggles over the control of the field of judgement and its values. (Ball, 2003, p. 216)

Ball questions "Who is it that is to determine what is to count as a valuable effective or satisfactory performance and what measures or indicators are considered as valid" (2003, p. 216)? His response is that "Typically, at least in the UK, these struggles are currently highly individualized as teachers, as ethical subjects, find their values challenged, or displaced, by the terrors of performativity" (2003, p. 216). Policy technologies are about more than securing change within the system, but are also fundamentally about the re-casting of teachers and "what it means to be a teacher" (p. 218). Often framed in the language of autonomy, deregulation, freedom and innovation policy technologies represent new forms of control in which a hollowed out state both steps back, and steps in, through new forms of “regulated self-regulation" (Jessop, 2002, p. 199). 
Teachers wishing to survive, or thrive, within these new forms of control need to reconstitute themselves as "neo-liberal professionals" with different policy technologies bringing forth distinctive identities (Ball, 2003, p. 217). All are graded and ranked based on an assessment that measures how much "value" they have "added." Individual contribution is what counts, made possible by the "datafication" (Roberts-Holmes, 2015) of many of the pedagogical and organizational aspects of school life. Collective identities are encouraged only in so far as they support corporate objectives (membership of "the team" or the "learning community"). More established and autonomous collectivities, such as teacher union membership, are rejected as part of "the destruction of solidarities based upon a common professional identity" (Ball, 2003, p. 219).

Hall and Noyes (2009) (discussing the same policy period as Carter and Stevenson's 2008 study) adopt a similar Foucauldian framework. In their study they seek to demonstrate how the experience of particular policy technologies in England in the mid-2000s, specifically the role of the national inspectorate, Ofsted, but also the policy at the time of “School Self Evaluation" (DfES \& Ofsted, 2004), were establishing new “regimes of truth" (Foucault, 1977). In their study they describe how a school designated as failing was transformed into an apparently successful one, following a radical re-engineering of the professional practices of teachers. At its core was the use of numbers to establish a new reality. As Hall and Noyes (2009) assert:

Statistics were fundamental to the regime of truth created within the educational discourse of the school. Aggregated lesson grades provided a proxy for quality of teaching and learning; Ofsted descriptors and numerical grades reduced the 
vocabulary for describing lessons, and even teachers, to simple hierarchical formulations. In this climate, passing judgement, on yourself or on others, becomes the ideal mode of talking about teaching. (Hall \& Noyes, 2009, p. 853).

Turning the world into one characterized by numbers imbued it with a non-negotiable sense of truth, in ways that parallel the use of numbers in neo-Taylorism. As Hall and Noyes demonstrate, the scope to challenge this new reality for those uncomfortable with it was limited. One option was to quit, which as Ball (2003) indicates, is simultaneously an act of resistance and capitulation. More likely is that teachers form professional identities that are reconstituted in order to align with the externally determined notion of the "good teacher" (Connell, 2009). In more extreme cases, the system encourages a range of unethical practices from system "gaming” (Guardian, 2016) through to more explicit examples of dishonesty (Turner, 2016). In Hall and Noyes'study they demonstrate powerfully how the school's quality assurance regime established a Panopticon-like system of self-surveillance and a form of control from within. Although, the system of school self-evaluation which Hall and Noyes had described has been withdrawn at a formal level in England (in the name of freeing schools from bureaucracy), there is ample evidence that outside of these formal systems the disciplinary mechanisms they brought forth remain largely intact.

Many others attest to similar experiences to those identified by Hall and Noyes, and have drawn on notions of performativity to make sense of the changing nature of teachers' work. Roberts-Holmes' (2015) study of the experience of early years educators showed how their work was increasingly being framed in performative terms with the need to demonstrate the satisfactory progress of pre-school children. His work highlights how performative 
cultures serve not only to increase the control over practitioners, but to shift pedagogical practice so that, in turn, the experience of students and young people becomes framed by performativity. From a very early age children are learning to live in a performative world. In this case Roberts-Holmes demonstrates how early years educators in his study undertook a form of "educational triage" (Roberts-Holmes, 2015, p. 308), whereby the children in their care were quickly assessed, ranked and allocated to groups depending on their relationship to a particular performance threshold. Those deemed close to the threshold were identified as high- need and provided with additional support, whilst those considered likely to achieve the threshold consistently and those with little or no chance of achieving the threshold, were considered lower priority, and correspondingly, received less support.

Such experiences sat uncomfortably with the teachers in Roberts-Holmes' study. The system challenged their professional beliefs and compromised their values. "Complex holistic child-centred principles, sensitive pedagogies and assessments were in danger of being marginalized" (Roberts-Holmes, 2015, p. 313) by the drive to both feed the system with the numbers it required and also meet the expectations of progress that teachers felt obliged to evidence for their own self-protection. None of this was without tension and, echoing Hall and Noyes, Roberts-Holmes describes teachers who tried to reconcile the need to perform with the urge to resist.

... there was evidence that some of the early years teachers questioned, challenged and resisted the performativity culture and retained, where they could, their childcentred focus. However, the intensification of early years governance has resulted in the "datafication" of early years teachers and children in which the public and constant hierarchical ranking, ordering and classification of children, teachers and 
schools constrained such democratic pedagogical spaces, visions and possibilities. (Roberts-Holmes, 2015, p. 313)

Roberts-Holmes presentation of this issue raises questions at the heart of this articlehow can teachers speak back to the numbers? What does "resistance" look like? What generates it, and how can we begin to explain either its presence or its absence?

At this point I return to the work of Stephen Ball, and an article co-written with Antonio Olmedo (Ball \& Olmedo, 2013) in which the authors specifically explore notions of resistance, emerging from Ball's 2003 analysis. In presenting their arguments Ball and Olmedo make clear their interest is in developing a "different" approach to resistance - one that speaks to "the particular plight of the teacher who stands alone in their classroom or their staff common room, and sees something 'cracked"” (Ball \& Olmedo, 2013, p. 85). In the same opening paragraph, they assert, "We have nothing critical to say about, and nothing but admiration for, the efforts of collective resistance." But, as they say in their conclusion, their aim is to avoid relying on "grand narratives, or simple normativities" (p. 94), and instead choose to focus on "subjectivity, transgression and possibilities" (p. 94). Such an approach stands in contrast to the labor process analysis and its emphasis on collective and organized action.

Ball and Olmedo's article originated from unsolicited email correspondence from teachers and educators who had contacted Stephen Ball to raise issues and open a discussion about his work on performativity and their own experience of working within performative systems. He quotes several of the emails, and the exchanges which followed, that highlight the ways in which these "normal" teachers working in the "normality" of their classrooms 
(Ball \& Olmedo, 2013, p. 86) are troubled by their experiences as "neo-liberal professionals" (Ball, 2003), and in some cases, how they have sought to challenge the policy technologies that frame their professional lives. In these cases, they do not resist against a specific institution, group or class, but challenge a "form of power" (Foucault, 1982, quoted in Ball \& Olmedo 2013). The nature of these email exchanges can be considered as a process of "problematization," in Foucauldian terms, whereby there is a rejection of polemics (with its apparent closing down of possibilities), followed by a focus on posing open questions grounded in the real experiences of subjects.

... it begins with questions that arise not necessarily from the [doctrinal] frameworks themselves but from our "lived experiences" in society. We can and should put these questions not only to the doctrinal frameworks (to "politics"), but also to a variety of frameworks and with no assumption that any or all of them will offer adequate answers. (Foucault, 1997, p. 113)

Ball and Olmedo argue that by posing questions in this way and by engaging in such dialogues, we begin to question not only what we do, but who we are. They assert "It requires the deconstruction and recreation of the self and a certain capacity to examine ourselves critically" (Ball \& Olmedo, 2013, p. 89) and from within the practices of performativity there emerge the possibilities of practices of resistance, described as "deciphering, understanding, unravelling and retranslating” (Ball \& Olmedo, 2013, p. 93). This is not high visibility resistance, of the type we might normally envision when we think of those who "fight back" (interestingly the phrase used by one of Ball's correspondents describing past efforts to resist). It is not about protests and picket lines, but rather it is a process of "self-overcoming" as the writers of the emails, articulate a process of "refusing the mundane ... turning away 
from excellence [as determined by others]. . . unsettling truths" (Ball \& Olmedo, 2013, p. 94). This is what Ball and Olmedo mean by "care of the self" as teachers question themselves, their work and their own role in reinforcing the world that troubles them. Through these reflexive practices, in this instance undertaken by the simple individual act of articulating ideas in emails, the teachers begin to question "the possibilities and impossibilities of transgression” (Ball \& Olmedo, 2013, p. 94).

In an article that illustrates many of these points, five scholars working in higher education (Duckworth et al., 2016) discuss how their experience of informal email exchanges between themselves as professional colleagues and collaborators progressively began to open up a "critical space" in which it became possible to develop alternative discourses to the performative, and masculinist, discourses that framed their working lives. The authors argue "the feminised critical spaces that may emerge from such communities are a multifaceted refuge or asylum, and a forum for "being” and for "being yourself”. (Duckworth et al., 2016 p. 13)

This is "care of the self" as described by Ball and Olmedo (2013), and it provides another significant example of resistance through a process of "self-writing" in which the act of articulating ideas opens up a reflective space to think otherwise. The perspective outlined above is helpful in making explicit the complex ways in which neoliberalism seeps under the skin of its subjects and becomes absorbed into the bloodstream. It reminds us of Raymond Williams' description of dominant ideas as "saturating the consciousness" (Williams in Apple, 2004, p. 4).

However, although these articles provide important examples of acts of resistance it is less clear how such critiques might develop into a more collective organized form. Whilst 
those in the labor process tradition may be accused of romanticizing resistance as something inevitable and heroic, those working in the perspective outlined here might be accused of the reverse. In disconnecting "resistance" from any organizational base there is little sense how resistance can grow into something beyond "the self"- there is no real sense of trajectory. The challenge is to find some way in between the romanticizing of inevitable resistance and the promotion of a form of resistance that only ever appears as a small part in a much bigger story. In looking for some theoretical way through this binary my intention is to seek some productive coming together of the two perspectives presented.

\section{RESISTANCE FROM BELOW AND WITHIN: BRINGING IDEAS BACK IN}

I have presented two different perspectives that seek to analyze and explain developments in teachers' work. These two perspectives demonstrate several points of difference and departure. They reflect a range of tensions such as those between structuralist and post-structuralist analyses, the collective and the individual or neoliberalism as a class project within capitalism (Robertson, 2000 and 2007) and neoliberalism as a new imaginary in which power assumes more diverse forms. These differences are meaningful and they are important to debate. However, too often the focus of criticism of individual approaches is poorly targeted and unproductive. For example, to accuse labor process theorists of a crude determinism is to fail to recognize the considerable shifts in thinking that have arisen as scholars have reassessed their predictions of working class resistance "dashed on the rocks of a renascent capitalism" (Burawoy, 2004, p. 13). In addition, criticisms of Ball and Olmedo's silence on collective resistance risks criticizing them for something they, quite explicitly, did not set out to do. 
A more productive approach is gained from identifying points of contact, and how these connections can act as starting points for thinking about "resistance." In so doing, I am aware of the dangers of a simplistic and atheoretical "best of both worlds" approach in which the two perspectives are unproblematically conjoined in an intellectual marriage of convenience. It is important therefore not to gloss over differences. However, with that caveat in mind, I think the shared focus on the power of numbers as a form of ideological control whereby teachers are recast as obedient employees in a system that places a premium on compliance provides a starting point to think further about "resistance" and the active development of it. Whether it is about the construction of hegemonic control or the development of a new imaginary, the power of numbers has become central to framing the world in which teachers live and work. There can be no understanding the work of teachers without understanding the "tyranny of numbers" (Ball, 2015), and the role numbers increasingly play in framing "regimes of practice" (Gunter \& Forrester, 2009). Numbers are now central to creating an apparently uncontestable truth in which teachers are measured, ranked, judged and rewarded or punished. It is numbers that have put the science into contemporary "scientific management" (Taylor, 1911). Numbers make real the targets which ensure that teachers focus only on "what works" with little time or energy to discuss "what matters" (Biesta, 2015). Both currents discussed in this article depend on turning the complex social process of learning into numbers in order to secure increased control of teachers' work through forms of coercion and consent.

In this final section I argue that drawing on social movement literature, in particular the tradition associated with frame theory, it becomes possible to not only connect the two perspectives outlined here but also to develop wider debates about the development of 
grassroots activism and "resistance". To illustrate these arguments, I will draw on a number of examples of action and activism in England that have developed in response to the policy agenda in that context. There is no attempt to analyze them systematically, or to make claims about their effectiveness as campaigns. They are offered as illustrations of emergent campaigns and movements which point to new possibilities and which are worthy of further research.

Much social movement literature has focused on how collective resistance develops in response to specific grievances (Tarrow, 2011; Tilly, 1978), whilst other traditions have focused on the way in which contexts are shaped by political opportunities and spaces (Kriesi, 2004). Both approaches have, at different times, been criticized for being overly deterministic, and frame analysis offers a fruitful way of thinking beyond these limitations. Fundamentally frame analysis is a process that emphasizes the importance of locating a problem (and its social and political elements) and identifying those responsible and counterposing alternatives ("re-framing") as a precursor to developing collective action (Noakes \& Johnston, 2005).

Oliver and Johnston (2000) identify four different dimensions of frames. First, frames provide cognitive structures within which individuals begin to make sense of their experience. Second, they become the potential basis for collective action "insofar as they are shared by enough individuals to channel individual behaviors into patterned social ones" (Oliver \& Johnston, 2000, p. 41). Third, frames offer a methodological tool for detailed analysis of the cognitive orientations shared by the collective, and finally, they provide a way of capturing the dynamic nature of cognitive frames, whereby frame formation is treated as a process rather than a snapshot. For Oliver and Johnston frames reflect "the cognitive process 
wherein people bring to bear background knowledge to interpret an event or circumstance and to locate it in a larger system of meaning” (Oliver \& Johnston, 2000, p. 45).

Thinking of this process of framing has important implications for how resistance strategies can be developed in the difficult circumstances identified by both the currents presented in this article. In this final section, I set out five key issues and how they might inform thinking about how to "speak back to the numbers."

First, and arguably most importantly, frame analysis prioritizes the importance of ideas and the need to be able to think otherwise about the world in which we work. Alternative ideas provide encouragement that another world is possible. Margaret Thatcher's assertion, invoked many times, that "there is no alternative" is a notion that has taken deep root in our collective psyche. In England, the drive to close down the spaces where alternative discourses can develop is well established, whether this is in the neoliberal workplace where dissent is increasingly recast as disloyalty (Stevenson, 2016) or the more explicit attempts to undermine the role of universities in educating future generations of teachers (Gibb, 2014). Frame analysis highlights the imperative of keeping alternative ideas alive, and for creating, defending and extending the spaces in which such ideas can breathe. One practical illustration of this is the creation of a loose network of UK academics who organize under the heading "Reclaiming Schools" (www.reclaimingschools.org). On their website the group claims:

We are often told there is no alternative to austerity, endless testing and targets, and forcing schools to become academies [equivalent to US Charter Schools]. This "dictatorship of no alternatives" cannot be overthrown without ideas. 
As a network of researchers we seek to challenge this by publicising evidence and arguments that offer a real alternative. We provide reliable knowledge on key issues such as tests, the National Curriculum, child poverty, Ofsted [the inspectorate], 'British values', literacy, and the government's misuse of statistical data.

(www.reclaimingschools.org)

The group's most recent intervention is a publication entitled "The Mismeasurement of Learning" (NUT, 2016), published by the National Union of Teachers. In the publication, scholars specializing in assessment issues explicitly seek to break the frame of "datafication," whilst also re-framing the debate around more positive alternatives.

Second, frame analysis points to the need to ground ideas in the concrete experiences of teachers. There is a recognition within social movement literature, most obviously the strand associated with mobilization theory, that the search for alternatives must derive from dissatisfaction with the here and now (Tilly \& Wood, 2013). Numbers underpin the policy technologies driving the intensification of teachers' work and generate practices that conflict with teachers' professional values. If teachers are to resist these processes, then any reframing must take teachers' grievances as its starting point, as they are rooted in experiences of both exploitation and alienation. Frame theory emphasizes the importance of ideas, but these ideas cannot float free from the lived experiences of teachers. The challenge is to connect ideas and experiences in ways that allow teachers to identify, make sense of, and articulate their feelings of injustice. The spontaneous development in 2016 of a "You can't 
test this" campaign illustrated this connection of activism and ideas. The campaign emerged when new national testing arrangements in primary schools in England attracted considerable opposition from many teachers. The aim of teachers involved in the campaign was to develop a range of learning opportunities in which outcomes explicitly could not be quantified - a form of "counter-datafication." In so doing, those involved began to reframe learning around a much richer notion of what teaching and learning could look like. According to the group's Facebook page "Teachers everywhere will be teaching brilliant things that can't be tested. Let's reclaim the classroom!" (https://www.facebook.com/events/1596835807251285/).

Third, frame analysis encourages us to think about resistance much more creatively than has often been the case. It remains the case that references to resistance invoke traditional images of collective action, often masculinist and ritualistic. There is commonly a hierarchy of resistance which privileges the hero activist, and trivializes, or renders invisible, the myriad forms of resistance in which individuals every day speak back to the tyranny of numbers. Ball and Olmedo (2013) and Duckworth et al. (2016) remind us that resistance has never been purely a set-piece process, but now more than ever, it looks diverse in form and de-centered in structure. In developing more inclusive notions of activism it is becoming increasingly important to think of the blogger alongside the union president. This is not to suggest an either/or bifurcation, but to make the case for a more inclusive understanding of "resistances" in which individuals and collectives may work in diverse and unpredictable ways. This is illustrated by the "You can't test this" campaign referred to above, but also the emergence of a group called "Let Our Kids be Kids" (https://letthekidsbekids.wordpress.com/). This group was formed by parents during the 2016 testing crisis in England and concerns about the impact of the tests on children. The group 
quickly focused its action on a national "stay away" of children from school on a day of standardized testing. However the group also organized alternative actions (such as an outdoor activity event on the day of the tests) that acted as practical examples of what a more creative curriculum might look like. In this sense the action emerged as a practical manifestation of re-framing.

It is also important to highlight how, in all the examples provided above, these groups make considerable use of social media. What is clear is that social media is opening up new possibilities for activism and organizing, one form of which is the role of the web as an important alternative space where reframing takes place (Kahn \& Kellner, 2004).

Fourth, frame analysis points to the need to work horizontally and to make connections. As indicated, Ball and Olmedo deliberately set out to speak to "the teacher who stands alone in their classroom or their staff common room, and sees something 'cracked"' (Ball \& Olmedo, 2013, p. 85). Countless numbers of teachers will recognize themselves in that single fraction of a sentence. Ball and Olmedo present "care of the self," whereby individual teachers problematize the world they inhabit and begin to both question it and reimagine it as a form of resistance. This is precisely the form of resistance that traditional analyses often render invisible. For much social movement theory such acts are neither social nor a movement. This should not obviate the analysis, but rather highlight the need to connect individual acts of resistance in ways that develop collective understandings.

Frame analysis encourages us to think about how individuals engaged in "care of the self' are able to share their concerns so that care of the self becomes care for each other. Transforming individual concerns into shared understandings becomes central to developing the collective responses required to make significant change possible. Perhaps the best 
example of how this horizontal organizing and alliance building has developed is an emerging national campaign in England called "More than a Score"

(https://morethanascore.co.uk/). This group formed from the often disparate and localized campaigns about testing identified above and now brings together teacher unions, parents groups, and specialist professional bodies. The very title of the group begins to reframe education in ways that challenges the reductivist nature of datafication. As the group's website asserts "National standardized tests used to rank and judge schools reduce children to statistics. This is grossly unfair - children are more than a score." It goes on to argue "We want not only to campaign for reform of the present system, but to advocate for a better alternative for assessment and accountability" (https://morethanascore.co.uk/our-vision/). Appropriately, the site also provides links to a number of research reports which make the case for alternative approaches to assessment and different from those adopted in English education policy.

The final element of frame analysis, and which I want to argue underpins all others, is the importance of the individuals engaged in this "ideas work." An obvious reference point for those involved in this work is Gramsci's (1971) conception of the "organic intellectual," whereby activists rooted within the subaltern movements provided the "intellectual and moral leadership" (Gramsci, 1971, p. 57) (the essence of Gramsci's notion of hegemony) that challenged dominant orthodoxies. This notion has been developed by many scholars, including Giroux (1988) who argued that teachers need to perform the role of "transformative intellectuals." Their function is "to develop a discourse that unites the language of critique with the language of possibility, so that social educators recognize that "they can make changes" and make "hope practical" (Giroux, 1988, p. 128). Such intellectuals are not in 
possession of a singular answer. Instead, they help others frame answers as all struggle collectively to make meaning from the world that presents as "cracked."

\section{CONCLUSION}

In concluding this article I want to respond to Hall and McGinity who assert that "theorizing and researching resistance at a time of widespread compliance has become an urgent issue for educational researchers" (Hall \& McGinity, 2015, p. 13) and argue that the contribution of "ideas work", and the need to "bringing ideas back in", are central to making resistance happen, howsoever defined. Acts of resistance, individual or collective, high profile or barely visible, emerge from the cracks and contradictions of an education system in which complex human processes are reduced to numbers and the engines that drive the machine are performativity and marketization. However, without the ability to see a world beyond the numbers, many acts of resistance will eventually be suffocated. Small, short term victories will be dwarfed by long-term setbacks. Ideas are central to nurturing and sustaining resistance. Being against something is what may draw individuals into organized action, but being for something is what is likely to sustain their activism. Without overstating their significance the emerging grassroots campaigns that oppose testing and seek to "reframe" the debate about education, may represent the emergence of a new cultural politics around core education issues (curriculum, pedagogy, assessment) that has not been seen in England since the early 1990s (Jones, 1994). What is also significant is the way such campaigns are mirrored in different parts of the world - indeed the "more than a score" strapline is used on both sides of the Atlantic ocean (see Hagopian, et al., 2014) 
However, just as I have argued that it is necessary to re-think our notion of resistance, frame theory invites us to rethink what it means to be an "activist." Those who act as the "organizers of ideas" (Stevenson, 2012) by taking a leading role in framing and re-framing issues in ways that open up creative possibilities are a more diverse group than often imagined. Such individuals need to be thought of as all those who, in Gramsci's words, perform the "function of intellectuals" (Gramsci, 1971, p. 9), namely by providing the intellectual leadership essential to reframing. Some of these individuals will look much as we imagine activists to look, probably playing leading roles in community advocacy groups or their education union, but many will not. Their actions will look quite different, perhaps writing a blog or running a journal club. Such work may appear insignificant, and in its failure to confront neoliberalism explicitly, may even be dismissed as not being in "the forefront of the struggle" (Compton \& Weiner, 2007, p. 3). However, as Oliver and Johnston (2000) assert, whilst framing processes do not, of themselves, persuade people to adopt new ideologies they can "initiate the journey" (Oliver \& Johnston, 2000, p. 47). Movements that can claim to be genuinely counter-hegemonic may be the ambition, but it is important to recognize that they will grow from the slow, steady and small-scale ideas work that takes place every day, but which needs to be recognized, valued and nurtured if it is to develop into something bigger and more significant.

Finally, I want to argue that frame theory's focus on ideas offers a useful way to "theory bridge" between competing perspectives in critical studies of teachers' work. As the pressures on teachers intensify it is increasingly important to understand how, and under what circumstances, "resistance" might emerge. Both structural and post-structural perspectives have much to contribute to understanding of these issues, but neither on their own, can claim 
the explanatory power to suggest that theoretical unitarism is sufficient. This article demonstrates how frame theory can bridge these two traditions, whilst also addressing limitations in both. Such an analysis points to complexity and uncertainty, but it also emphasizes possibility when teachers find ways to speak up and speak back to the numbers. 


\section{REFERENCES:}

Allen, A. (2014). Benign violence: Education in and beyond the Age of Reason. Basingstoke: Palgrave Macmillan.

Anyon, J. (2014). Radical possibilities: Public policy, urban education, and a new social movement. London: Routledge.

Apple, M.W. (2004). Ideology and curriculum. London: RoutledgeFalmer.

Apple, M.W. (2005). Education, markets and an audit culture. Critical Quarterly 47 (1-2), 11-29.

Apple, M. W. (2013). Can education change society? London: Routledge.

Bach. S, Kessler. I \& Heron. P (2006). Changing job boundaries and workforce reform: The case of teaching assistants. Industrial Relations Journal 37(1), 2-21.

Ball. S. J. (1988). Staff relations during the teachers' industrial action: Conflict, context and proletarianization. British Journal of Sociology of Education, 9 (3), 289-306.

Ball, S. J. (1998). Big Policies/Small World: An introduction to international perspectives in education policy. Comparative Education, 34 (2), 119-130.

Ball, S. J. (2003). The teachers' soul and the terrors of performativity. Journal of Education Policy, 18 (2), 215-228.

Ball, S. J. (2013). Foucault, power and education. Abingdon: Routledge.

Ball, S. J. (2015). Education, governance and the tyranny of numbers. Journal of Education Policy. 30 (3) 299-301. 
Ball, S. J. \& Olmedo, A. (2013). Care of the self, resistance and subjectivity under neoliberal governmentalities. Critical Studies in Education. 54 (1) 85-96.

Berry, J. (2016). Teachers undefeated: How global education reform has failed to crush the spirit of educators. Stoke-on-Trent: Trentham Books.

Biesta, G. J. (2015). Good education in an age of measurement: Ethics, politics, democracy. London: Routledge.

Braverman, H. (1974). Labor and monopoly capital: The degradation of work in the twentieth century. New York: Monthly Review.

Burawoy, M. (1979). Manufacturing consent: Changes in the labor process under monopoly capitalism. University of Chicago Press: Chicago.

Burawoy, M. (2004). Another thirty years. Retrieved from http://burawoy.berkeley.edu/Biography/Thirty\%20Years.pdf [special preference to a Chinese translation of Manufacturing consent].

Carlson, D. (1987). Teachers as Political Actors: From Reproductive Theory to the Crisis of Schooling. Harvard Educational Review. 57 (3), 283-308.

Carter, B. (1997). The restructuring of teaching and the restructuring of class. British Journal of Sociology of Education. 18 (2), 201-215.

Carter, B. \& Stevenson H. (2008). Workforce remodeling, teacher trade unionism and school-based industrial relations: Full Research Report ESRC End of Award Report, RES-062-23-0034-A. Swindon: ESRC

Carter, B. \& Stevenson, H. (2012). Teachers, workforce remodeling and the challenge to labor 
process analysis. Work, Employment and Society. 26 (3), 481-496.

Carter, B., Stevenson, H. \& Passy, R. (2010). Industrial relations in education: Transforming the school workforce. London: Routledge.

Compton, M. \& Weiner, L. (2007). The global assault on teaching, teachers and teacher unions. In M. Compton and L. Weiner (Eds), The global assault on teaching, teachers and the unions: Stories for resistance (pp. 3-9). New York NY: Palgrave Macmillan.

Connell, R. (1985). Teachers' work. London: HarperCollins.

Connell, R. (2009). Good teachers on dangerous ground: Towards a new view of teacher quality and professionalism. Critical Studies in Education. 50 (3), 213-229.

Department for Education and Skills (DfES) (2003). Raising standards and tackling workload: A national agreement. Retrieved from http://dera.ioe.ac.uk/540/

Department for Education and Skills (DfES) \& Ofsted (2004). A new relationship with schools: Improving performance through school self-evaluation, London, DfES.

Duckworth, V., Lord, J., Dunne, L., Atkins, L., \& Watmore, S. (2016). Creating feminised critical spaces and co-caring communities of practice outside patriarchal managerial landscapes. Gender and Education, 28 (7), 1-15.

Fairbrother, P. (1996). Workplace trade unionism in the state sector. In P. Ackers., C. Smith., and P. Smith (Eds.), The new workplace and trade unions (pp. 110-148). London: Routledge.

Fairbrother, P. (2000). British trade unions facing the future, Capital and Class (71), 47-78.

Foucault, M. (1977). Discipline and punish: the birth of the prison. London: Penguin. 
Foucault, M. (1982). The subject and power. In H. Dreyfus \& P. Rabinow (Eds.), Michel Foucault: Beyond structuralism and hermeneutics (pp. 208-226). Chicago, IL: University of Chicago Press.

Foucault, M. (1997). Ethics: Subjectivity and truth. The essential works of Michel Foucault, 1954-1984 (Vol. 1). New York, NY: The New Press.

Freire, P. (1970). Pedagogy of the oppressed. London: Penguin.

Gall, G. (1998). The prospects for workplace trade unionism: Evaluating Fairbrother's union renewal thesis. Capital \& Class, 22 (3), 149-157.

Gamson, W., Fireman, B. \& Rytina, S. (1982). Encounters with unjust authority. Homewood IL: Dorsey Press.

Gewirtz, S. (1997). Post-welfarism and the reconstruction of teachers' work in the UK. Journal of Education Policy, 12 (4), 217-231.

Gibb, N. (2014). Teacher unions aren't the problem - universities are. Retrieved from https://www.theguardian.com/commentisfree/2014/apr/23/teaching-unions-arentproblem-universities-schools-minister.

Goodrich, C. (1920). The frontier of control: A study in British workshop politics. London: Pluto Press (revised edition 1975).

Giroux, H. (1988). Teachers as intellectuals: Towards a critical pedagogy of learning. Westport, CT: Bergin and Garvey.

Golin, S. (2002). The Newark teacher strikes: Hopes on the line. New Brunswick, NJ: Rutgers University Press. 
Gramsci, A. (1971) Selections from the prison notebooks. London: Lawrence and Wishart.

Grek, S. (2009). Governing by Numbers: the PISA effect in Europe. Journal of Education Policy, 24 (1), 23-37.

Grek, S. (2015). Seeing from the top of the tower: PISA and the new governing panoramas in Europe. Compare - A Journal of Comparative and International Education, 45 (3), 479-481.

Guardian, (2016) Schools under scrutiny in crackdown on league table 'gaming, The Guardian, Retrieved from https://www.theguardian.com/education/2016/apr/08/gcseleague-table-gaming-schools-crackdown

Gunter, H. M. \& Forrester, G., (2009). School leadership and education policy-making in England. Policy Studies, 30 (5), 495-511.

Hagopian, J. (Ed) (2014). More than a score: the new uprising against high-stakes testing. Chicago: Haymarket Books.

Hall, D. \& McGinity, R. (2015). Conceptualizing teacher professional identity in neoliberal times: Resistance, compliance and reform. Education Policy Analysis Archives, 23 (88). 1-17.

Hall, C. \& Noyes, A. (2009). New regimes of truth: The impact of performative school selfevaluation systems on teachers' professional identities. Teaching and Teacher Education, 25 (6), 850-856.

Hammersley-Fletcher, L. (2008). The impact of workforce remodeling on change management and working practices in English primary schools. School Leadership \& 
Management, 28 (5) 489-503.

Hannaway, J. \& Rotherham, A. (2006). Collective bargaining and education: Negotiating change in today's schools. Cambridge, MA: Harvard Education Press.

Harvie, D. (2006). Value production and struggle in the classroom: teachers within, against and beyond capital. Capital and Class, 88 (Spring), 1-32.

Horn, B. (2014). Movements or a moment: Teacher resistance to neoliberal education reform. Forum: for promoting 3-19 comprehensive education. 56 (2), 277-286.

Hutchings, M. (2010). Review of 'Industrial relations in education: Transforming the school workforce'. Workplace: A journal of academic labor. 17. Retrieved from http://ices.library.ubc.ca/index.php/workplace/article/view/182298

Hutchings, M., Seeds, K., Coleman, N., Harding, C., Mansaray, A., Maylor, U., Minty, S. \& Pickering, E. (2009). Aspects of school workforce remodeling: Strategies used and impact on workload and standards. Nottingham: Department for Children, Schools and Families.

Ingersoll, R. M. (2009). Who controls teachers' work? Power and accountability in America's schools. Cambridge, MA: Harvard University Press.

Jessop, B. (2002). The future of the capitalist state. Cambridge: Polity.

Jones, K. (1994). A new kind of cultural politics? The 1993 boycott of testing. Changing English, 2(1), 84-110.

Jones, K. (2016). Education in Britain: 1944 to the present, (2nd edition). Cambridge: Polity Press. 
Kahn, R., \& Kellner, D. (2004). New media and internet activism: From the 'Battle of Seattle' to blogging. New Media \& Society, 6(1), 87-95.

Kriesi, H. (2004). Political context and opportunity. In D. A. Snow, S.A. Soule and H. Kriesi (Eds) The Blackwell companion to social movements (pp 67-90). Oxford: Blackwell.

Kumar, P., \& Schenk, C. (2006). Union renewal and organizational change: A review of the literature. In P. Kumar and C. Schenk (Eds) Paths to union renewal: Canadian experiences (pp. 29-60). Toronto: University of Toronto Press.

Levin, B. (1998). An epidemic of education policy: (What) Can we learn from each other? Comparative Education. 34 (2), 131-141.

Lyotard, J.F. (1984). The postmodern condition: A report on knowledge. Minneapolis: University of Minnesota Press.

Marx, K. (1990). Capital: Critique of political economy, vol.1. Harmondsworth: Penguin.

Moe, T. M. (2002). Politics, Control, and the Future of School Accountability. Paper presented at the Conference on 'Taking account of accountability', Kennedy School of Government, Harvard University. Retrieved from http://files.eric.ed.gov/fulltext/ED477176.pdf

Murphy, M. (1990). Blackboard unions: The AFT and the NEA 1900-1980. Ithaca, NY: Cornell University Press.

Noakes, J. \& Johnston, H. (2005). Frames of protest: A road map to a perspective. In H. Johnston and J. Noakes (Eds.), Frames of protest: social movements and the framing perspective (pp. 1-29). Oxford: Rowman and Littlefield.

N.U.T. (2016). The mismeasurement of learning: how tests are damaging children and 
primary education, London: N.U.T.

Oliver, P. \& Johnston, H. (2000). What a good idea! Ideologies and frames in social movement research. Mobilization: An International Quarterly. 5 (1), 37-54.

Ozga, J. (2009). Governing education through data in England: From regulation to selfregulation. Journal of Education Policy, 24 (2), 149-162.

Ozga, J. \& Lawn, M. (1981). Teachers, professionalism and class: A study of organized teachers, London: Falmer Press.

RIG (Rewards and Incentives Group) (2005) STRB: Evidence from the Rewards and Incentives Group: 25th May 2005. Retrieved from http://www.teachernet.gov.uk/_doc/8454/20050526 STRB JOINT EVIDENCE Final.doc.

Reid, A. (2003). Understanding teachers' work: Is there still a place for labor process theory? British Journal of Sociology of Education, 24 (5), 559-573.

Rieser, R. (2016). The teachers' action 1984-86: Learning lessons from history. Forum: for promoting 3-19 comprehensive education, 58 (2), 267-273.

Rizvi, F. \& Lingard, B. (2010) Globalising education policy. London: Routledge.

Roberts-Holmes, G. (2015). The "datafication" of early years pedagogy: "If the teaching is good the data should be good, and if there's bad teaching there is bad data." Journal of Education Policy, 30 (3), 302-315.

Robertson, S. (2000). A class act: Changing teachers' work, the state and globalization. New York: Falmer Press. 
Robertson, S. (2007). "Remaking the world": Neoliberalism and the transformation of education and teachers' labor. In M. Compton and L. Weiner (Eds.), The global assault on teaching, teachers and the unions: Stories for resistance (pp. 11-27). New York NY: Palgrave Macmillan.

Seifert, R. (1987). Teacher militancy: A history of teacher strikes 1896-1987. London: Falmer Press.

Seifert, R., \& Li, Y. (2014). Consent and dissent: A study of the reaction of Chinese school teachers in Guangzhou City schools to government educational reforms. FIRE: Forum for International Research in Education, 1(2).

Sellar, S. \& Lingard, B. (2014). The OECD and the expansion of PISA: new global modes of governance in education. British Educational Research Journal. 40 (6), 917-936.

Sen, A. (2015). The economic consequences of austerity. Retrieved from http://www.newstatesman.com/politics/2015/06/amartya-sen-economic$\underline{\text { consequences-austerity }}$

Sinclair, J., Ironside, M. \& Seifert, R. (1996). Classroom struggle? Market oriented education reforms and their impact on the teacher labor process. Work, Employment and Society, $10(4), 641-661$.

Slaughter, S. \& Leslie, L. (1997). Academic capitalism: Politics, policies and the entrepreneurial university. Baltimore, MA: John Hopkins University Press.

Smyth, J. (2001). Critical politics of teachers' work: An Australian perspective. New York: Peter Lang Publishing. 
Spring, J. (2014). Globalization of education: An introduction. London: Routledge.

Steiner-Khamsi, G. (2003). The politics of league tables. Journal of Social Science Education. Retrieved from http://www.jsse.org/index.php/jsse/article/view/470

Stevenson, H. (2007). Restructuring teachers' work and trade union responses in England: Bargaining for change? American Educational Research Journal, 44 (2), 224-251.

Stevenson, H. (2012) Teacher leadership as intellectual leadership: creating spaces for alternative voices in the English school system. Professional Development in Education, 38 (2), 345-360.

Stevenson, H. (2016). Challenging school reform from below: Is leadership the missing link in mobilization theory? Leadership and Policy in Schools, 15 (1), 67-90.

Stevenson, H. \& Wood, P. (2013). Markets, managerialism and teachers' work: the invisible hand of high stakes testing in England. International Education Journal: Comparative Perspectives, 12 (2).

Tarrow, S. (2011). Power in movement: Social movements and contentious politics. Cambridge: Cambridge University Press.

Taubman, P. M. (2009). Teaching by numbers: Deconstructing the discourse of standards and accountability in education. London: Routledge.

Taylor, F. W. (1911). The principles of scientific management. London: Harper.

Tilly, C. (1978). From mobilization to revolution. New York: McGraw-Hill.

Tilly, C., \& Wood, L. (2013). Social movements 1768-2012 ( $3^{\text {rd }}$ edition). London: Paradigm.

Turner, E. (2016). Education through the (cheating) looking glass. Retrieved from 
https://wp.nyu.edu/politicsofprivatization/2016/05/19/blog-post-education-

privatization-through-the-cheating-looking-glass-by-erica-turner/

Verger, A., Fontdevila, C. \& Zancajo, A. (2016). The privatization of education: A political economy of global education reform. New York, NY: Teachers College Press. 